\title{
Differentiation of the Territory of Tatarstan Republic into Zones Due to their Significance for Domestic and National and International Tourism
}

\author{
Shabalina S.A. \\ Kazan Federal University, Institute of Management, Economics and Finance, Kazan, 420008, Russia
}

Rubtzov V.A.

Kazan Federal University, Institute of Management, Economics and Finance, Kazan, 420008, Russia

Pratchenko O.V.

Kazan Federal University, Institute of Language, 420008, Kazan, Russia

\section{Doi:10.5901/mjss.2014.v5n24p398}

\section{Abstract}

Tourism has an advantageous multiplier effect and severs as an accelerator of the social-economic development. Using a method of a component analysis the most significant indexes for differentiation of territory of Republic Tatarstan with purposes of recreation and tourism were detected. Map - models were constructed and by their superposition the integrated map of a recreational potential of Tatar Republic was obtained and the attractive areas for rest and tourism were detected.

Keywords: recreational system, domestic tourism, international tourism, division into districts, tourist zone.

\section{Introduction}

To organization the environment, to preserve and to maintain its condition in accordance with the requirements of environmental management is necessary for recreational activities. In this regard, good organization of recreational activities is possible only if recreational needs are accepted as the starting positions [1], [2]. In the study of organization of recreational activities the complex structures, the elements of which are closely interconnected by direct links and feedback, are revealed. Thus, the system consisting of heterogeneous but interrelated components - natural and culturalhistorical recreational resources, engineering and infrastructure facilities, recreation organizers and leisure travelers, is formed and developed. In the frames of this territorial-recreation system (TRS) recreational activities is implemented; it is characterized by functionality, integrity, hierarchy, stability and dynamics [3]. As any complex system, it will consist of subsystems which form integral formations. That is why, it is necessary to consider it as an industrial and territorial model.

The aim of the work is spatial analysis of recreational-touristic system of the Republic of Tatarstan. We offer to distinguish two groups of factors that give rise to the demand to create the TRS and to realize this demand. The first group determines the basic properties of the TRS: integrity, diversity, dynamism and reliability. The second group of factors is connected with properties and processes occurring in the system (recreational resources, accommodation, production, transportation, etc.).

Вторая группа факторов связана со свойствами и процессами, происходящими в системе (рекреационные ресурсы, расселение, производство, транспорт и др.).

\section{Methods}

The concept of spatial-network analysis is proposed as a model of the research process of the recreational complex as a system. Nature of the research is necessary to carry out in two directions: the study of object-centered systems in the areas of the territorial concentration of natural-geographical and socio-cultural recreational resources of the region and subject-centered recreation systems formed in cities and suburban areas [4].

The integral picture of the distribution of the values of recreation and tourism potential (TRP) on the territory, received in the frames of OTE, with the administrative districts of RT as these frames, was the result of the first stage. 
The evaluation analysis of the recreational potential of the Republic of Tatarstan and possibility of its use showed that there are many unsolved problems, and the methodological aspect is among them: the problem of assessment of recreational resources, determination of the degree of possibility of ratio of various environmental components, the problem of territorial differentiation and recreational zoning and construction of a series of single-scale functional mapsmodels [5].

Natural, cultural-historical and socio-economic resources were analyzed. 3 key figure blocks that are analyzed, with the following calculation of partial integral estimates and interpretation of the results, were identified as a result. The principle of objectivity and comparability of results was the main basis of the evaluation [6].

The widely used in statistics and geography method of the sum of normalized values by the maximum index using the following formula was used for calculation of the block values of natural-recreational, cultural-historical, infrastructural and recreational-touristic potentials:

иП $\Pi_{i}=\sum_{j=1}^{m} k_{j} a_{i j}$

where $И \Pi_{i}=$ the integral indicator of the corresponding block i,

$a_{i j}$ - normalized value of the j-indicator of the resourcing of the i-region;

$k_{j}$ - weighing coefficient of $\mathrm{j}$ indicator;

$k_{j}=\frac{I j}{I \mathrm{max}^{\prime}}$, where $I j-$ information value of $j$-indicator determined as the sum of all coefficients of correlation of $j$ indicator with the others; $I$ max - maximum value of information value among all indicators.

This form of calculation of the block index allows to determine the point of recreation-resource potential of the area, and the index share in recreational-touristic potential - with the help of the weighing coefficients determined by expertise. Integral natural and recreational potential is determined from the table by six natural components. Due to the fact that the climatic, geological and geomorphological resources do not have significant diversity within the studied area, and the other resources (balneology, hydrological, PA) often determine recreational specialization, the weighing coefficients were used, and the final value of the integral natural-recreational potential for every municipal district is defaulted (Table 1).

Cultural and historical heritage of the region plays an essential role in the formation of recreational-touristic potential [7]. The integral index of cultural and historical recreational potential was obtained in result of the evaluation of availability of the territory of the Republic of Tatarstan by cultural and historical sites by five groups of indicators (Table 1).

Table 1. Recreational-touristic potential of regions of the Republic of Tatarstan

\begin{tabular}{|l|c|c|c|c|}
\hline \multirow{2}{*}{ Region } & \multicolumn{2}{|c|}{ Blocks of formation of recreational-touristic potential } & \multirow{2}{*}{ Integral total recreational-touristic } \\
\cline { 2 - 4 } & Natural-recreational & Cultural-historical & Infrastructural & 7,6 \\
\hline Agryzsky & 1,8 & 2,3 & 3,5 & 8,7 \\
\hline Aznakaevsky & 2,3 & 3,1 & 3,3 & 7,5 \\
\hline Aksubaevsky & 2,7 & 2,3 & 2,5 & 10,4 \\
\hline Aktanyshsky & 4,0 & 3,3 & 3,1 & 9,6 \\
\hline Alekseevsky & 3,7 & 2,5 & 3,4 & 7,7 \\
\hline Alkeevsky & 2,0 & 2,7 & 3,0 & 8,4 \\
\hline Almetyevsky & 2,6 & 2,7 & 3,1 & 8,2 \\
\hline Apastovsky & 2,2 & 3,2 & 2,8 & 8,7 \\
\hline Arsky & 3,3 & 2,7 & 2,7 & 9,1 \\
\hline Atninsky & 3,0 & 3,3 & 2,8 & 6,7 \\
\hline Bavlinsky & 2,0 & 2,3 & 2,4 & 9,8 \\
\hline Baltasinsky & 3,1 & 3,4 & 3,3 & 8,6 \\
\hline Bugulminsky & 3,0 & 3,3 & 2,3 & 10 \\
\hline Buinsky & 4,3 & 3,3 & 2,4 & 8,8 \\
\hline Verkhneuslonsky & 2,7 & 3,0 & 3,1 & 9,7 \\
\hline Vysokogorsky & 3,3 & 3,3 & 3,1 & 8,5 \\
\hline Drozhzhanovsky & 3,3 & 2,5 & 2,7 &, 5 \\
\hline Elabuzhsky & 3,7 & 3,3 & 3,5 & 8 \\
\hline Zainsky & 2,3 & 2,3 & 3,4 & 10,7 \\
\hline Zelenodolsky & 4,5 & 2,9 & 3,3 & 8,6 \\
\hline Kaibitsky & 2,5 & 3,1 & 3,0 & 8,1 \\
\hline Kamsko-Ustyinsky & 2,2 & 2,5 & 3,4 & 9,9 \\
\hline Kukmorsky & 3,6 & 3,4 & 2,9 & \\
\hline
\end{tabular}




\begin{tabular}{|c|c|c|c|c|}
\hline Laishevsky & 3,3 & 3,3 & 3,4 & 10 \\
\hline Leninogorsky & 3,2 & 2,4 & 3,3 & 8,9 \\
\hline Mamadyshsky & 3,0 & 3,1 & 2,7 & 8,8 \\
\hline Mendeleevsky & 2,7 & 3,1 & 3,7 & 9,5 \\
\hline Menzelinsky & 3,0 & 2,9 & 3,4 & 9,3 \\
\hline Muslyumovsky & 2,8 & 2,4 & 3,5 & 8,7 \\
\hline Nizhnekamsky & 3,7 & 3,1 & 3,3 & 10,1 \\
\hline Novosheshminsky & 2,0 & 2,8 & 3,3 & 8,1 \\
\hline Nurlatsky & 4,1 & 3,2 & 2,7 & 10 \\
\hline Pestrechinsky & 3,2 & 3,4 & 3,4 & 10 \\
\hline Rybno-Slobodsky & 3,0 & 3,1 & 2,7 & 8,8 \\
\hline Sabinsky & 3,7 & 3,4 & 3,5 & 10,6 \\
\hline Sarmanovsky & 2,4 & 3,4 & 3,1 & 8,9 \\
\hline Spassky & 2,4 & 2,3 & 3,4 & 10,1 \\
\hline Tetyushsky & 1,9 & 3,0 & 3,2 & 8,1 \\
\hline Tukaevsky & 3,5 & 3,3 & 3,7 & 10,5 \\
\hline Tyulyachinsky & 3,6 & 2,9 & 3,0 & 9,5 \\
\hline Cheremshansky & 3,0 & 3,4 & 2,7 & 9,1 \\
\hline Chistopolsky & 3,0 & 2,7 & 3,3 & 9 \\
\hline Yutazinsky & 1,9 & 3,2 & 3,2 & 8,3 \\
\hline
\end{tabular}

Infrastructure capacity was obtained taking into account the available statistics that characterize the level of development of recreational facilities in the municipalities. Integration of block estimates allowed to provide a generalized integral recreational and touristic potential.

Comprehensive analysis of the recreational use of the territory is necessary to assess the current condition and prospects of development of the system. Recreational zoning - the division of the regional territory by uniformity of features and the nature of recreational use - is one of the key methods of the analysis [8,9]. Verification procedure of the boundary, when isolated OTE with similar values which tend to localize in certain parts of the territory and which form the core are outlined, was used.

\section{Results}

The map of the Republic of Tatarstan that lets to talk about the existing object-centered systems in the areas of territorial concentration of administrative districts, became the result of the studies $[10,11]$. Geographically, the functional structure of the republic has a polycentric structure of the territorial-recreational system. Typology of RTR is determined in three directions: the main functional focus on external or local demands and the level of development of the structure.

Typology of the regions of the RT with determination of of taxonomic rank (first, second and third) was carried out. The recreational-touristic areas of local significance (PTT) make up the third level with the lowest values $(6,7-8.3)$. The recreational-touristic areas (RTR) of regional significance with values ranging from 8.4 to 10 will make up the second level. The recreational-touristic complexes (RTC) of the federal and possibly international importance with values more than 10 will make up the first level. it is possible to set up 10 recreational-touristic areas according to the final total index of the recreational-touristic potential of natural-recreational, cultural-historical resources and conditions of socio-economic development presented in the municipality, within the republic (Figure 1).

Three regions of the republic (Zelenodolsky, Elabuzhsky and Spassky) have federal importance for the development of recreation and tourism. The lack of common borders and remote location from each other allows to consider them as independent and self-sufficient development centers. The analysis of the factors of formation and development of every region shows that they are and will be the centers of recreation. This is due to the presence of unique recreational resources that meet the requirements of the most mass cycles of pastime. The territories of the regions are historically characterized as the most developed part. Recreational specialization influences the organization of the territory. Optimization processes and efficiency increase of service of holidaymakers will play an important role to optimize.

Prikazansky RTR includes three municipalities (Laishevsky, Vysokogorsky and Verkhneuslonsky). The total area is 5139.3 square kilometers. The territory can be considered as an forming recreational complex, the functional specialization of which is of recreational and educational character orienting the local population for the weekend rest. Analysis of the factors of formation and development shows that areas near the large metropolitan area (Kazan), with 
high potential of recreational demand and a high coefficient of transport accessibility will become areas with high concentration of recreational-touristic institutions aimed at short-term rest.

Environmental and event tourism is a promising direction. Creation of different types of recreational parks, organization of folk art festivals will be important issues of the organization.

Arsky RTR corresponds to municipality of the same name; it is an independent integral system. Such isolated location is due to the remoteness from the capital and the presence of rich cultural-historical potential that allows to develop recreational-cognitive and ethnographic direction.

Prikamskaya RTR includes the territory of 4 regions, which is $8,010 \mathrm{~km}^{2}$. It can be regarded as a young recreational area of medical and health character. Availability of the resort of national importance (Bakirovo) and the regional network of health centers "Tatfet" favors the formation of the zone to serve the demands of population of industrial cities. Future prospects are connected with the development of natural and recreational resources. All these regions are about the same in terms of material and technical facilities and transport-geographical location. Available reserves of balneology resources are small but they allow us to build a number of republican sanatoriums. Tukaevsky and Nizhnekamsk regions can be both the republican, as well as the federal centers of medical and health and environmental spheres.

Predvolzhskaya RTR includes 6 districts (Kaybitsky, Kamsko-Ustyinsky, Apastovsky, Tetyushsky, Buinsky, Drozhzhanovsky). The total area is $7453.2 \mathrm{~km}^{2}$. Recreational potential is low. The group of regions is not adapted and not promising for development of recreation and tourism industry, except the Tetyushsky region. Some territories can be used only for short-term rest and for summer camps and recreation camps of local importance.

Prekamskaya RTR includes eight municipal districts with total area of $11222.3 \mathrm{~km}^{2} 11$. Values of some potentials [12] are, as a rule, average or below average. The level of infrastructural capacity is low. The area is characterized by combination of relatively intact nature and economic development. There are prerequisites for organization of some recreational activities (especially the fishing and hunting).

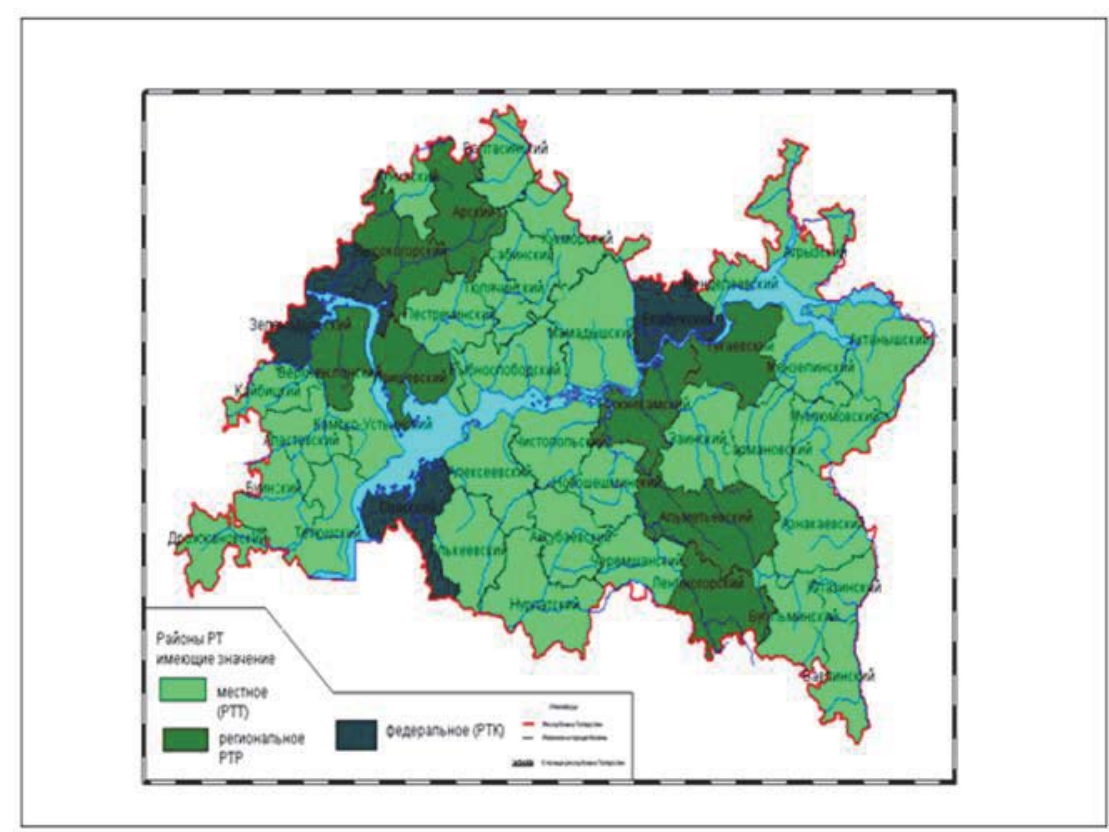

Fig. 1. Recreational-touristic zones of the Republic of Tatarstan

Zakamskaya RTR includes 7 regions with a total area of $12049.3 \mathrm{~km}^{2}$. This area is mainly the region of rural settlements. There is a close relationship of peculiarity of population settlement with historical-cultural resources (Chistopol, Bilyarsk). Position areas can be defined as a "backup" for recreation not only close to his industrial areas, but also the more remote areas. Recreational activities will only participate in local entities, specialization in the development of cultural recreation.

Location of the regions can be determined as "reserve" for recreation of not only nearby industrial areas, but also of more remote ones. Recreational activities will participate only in local entities, narrow specialization in development of cultural-educational recreation. 
Vostochnaya RTR includes 11 districts with a total area of $16831.2 \mathrm{~km}^{2}$. In the near future the group will not be universally and evenly mastered. Overall recreational territory of the region is either mastered weakly (Zainsky, Bugulminsky, Menzelinsky), or is not mastered. We can assume that recreational areas around cities or regional centers for a short rest of local population will form there.

\section{Conclusion}

The structure of the recreational-touristic resources of the republic is comparable with development trends of the world tourism, and it allows to say about preferential development of such directions as cruise, educational, event, ecological, medical and health tourism and leisure. However, now we can say just about the potential of the republican tourism as the possibility of its development to a greater extent rather than about its real development.

\section{References}

Ogonowska, M., D. Torre Sustainable tourism and the emergence of new environmental norms. European Journal of Tourism Research (2013) 6(2), pp. 141-153

Shian Loong, B. L. A molecular treatment of successful destinations: revisiting methodological individualism. European Journal of Tourism Research 5(2), (2012)pp. 106-117.

Blaug,M.(1997) "Why are Covent Garden seat prices so high?" in Towse R.(Ed.) Cultural Economics: the Arts, theHeritage and the Cultural Industries, Vol.I,Cheltenham,EdwardElgar,pp.302-322.

Gabor,A.(1980) Pricing: Principles and Practice. London, Heinemann.

Yeoman,landA.Ingold(1997) Yield Management:Strategies for the Service Industries,London,Cassell.

Hall, P. (2000) The changing role of capital cities. Plan Canada 40(3), 8-12.

Maitland, R. (2006) How can we manage the tourist-historic city? Tourism strategy in Cambridge, 1978-2003. Tourism Management 27, 1262-1273.

Gabdrakhmanov N.K., Rubtzov V.A., Shabalina S.A., Rozhko M.V. Kucheryavenko D.Z. The role territorial organization of cities in the touristic attraction of the region on the example of the Republic of Tatarstan. Life Sci J 2014;11 (12):451-455] (ISSN:1097-8135). http://www.lifesciencesite.com.89

Ritchie, B.W. and Peirce, S. (2007) National Capital Tourism: Marketing, Planning and Development Issues. Sustainable Tourism CRC, Gold Coast, Australia.

Gabdrakhmanov N.K. and Rozhko M.V. Positioning of Volga Federal District Regions by Demographic Situation Index // World Applied Sciences Journal, Volume 30 Number 6, 2014. - pp.792-795

Gabdrakhmanov N.K. and Rubtsov V.A. Tourist and Recreational Positioning of Tatarstan Republic: Cluster Analysis // World Applied Sciences Journal 30 (Management, Economics, Technology \& Tourism), 2014 - pp.202-205

Gabdrakhmanov N.K. and Rubtzov V.A. Geodemographic Polarization Processes: Municipal Level (The Case of the Kukmorsky Municipal District of the Republic of Tatarstan) // World Applied Sciences Journal, Volume 30 Number 10, 2014. - pp.1317-1320 